\title{
Timeliness, relevance, freedom: on Steve Buckler's reading of Hannah Arendt
}

Review symposium on Steve Buckler, Hannah Arendt and Political Theory:

Challenging the Tradition (Edinburgh University Press: Edinburgh, 2011)

\author{
Garrath Williams
}

Department of Politics, Philosophy and Religion, Lancaster University, UK g.d.williams@lancaster.ac.uk

[Final accepted manuscript - published in the European Journal of Political Theory 13(3): 366-71. 2014. doi:10.1177/1474885114527710]

If the original question of moral philosophy is, as Kant had it, 'What ought I to do?' then one might suppose that political philosophy should address the question 'What ought we to do?' Certainly, much political philosophy has been occupied with a question that looks rather similar, 'What ought we to achieve?' According to their professional self-image, philosophers are adept at scrutinising the terms in which questions are posed. But the nature of the 'we' involved has attracted less attention than it might. So has the relation between action (which must always begin from a given situation) and projected achievements (which may be sketched without any attention to who acts or where those actors must start from).

Steve Buckler paints a compelling portrait of a "political theorist" who famously claimed to have "said good-bye to philosophy once and for all" (quoted 3). Hannah Arendt's achievement is nonetheless consummately philosophical - in part, because it involves a fundamental critique of political philosophy's traditional questions. She contends that the questions 'What ought we to do?' or 'What ought we to achieve?' only make sense if one disregards the intrinsic limits of politics - the predicaments of action and the precariousness of power, the contingency of every starting point and the fragility of any achievement. By failing to examine their own questions, philosophers too often pretend to a disembodied legislative position above the hubbub. In contemporary political philosophy, this results not so much in critical distance as an unstable mix of domestication (so many variants on liberal democracy [10f)]) and irrelevance (a preoccupation with abstract principles that no actor or polity could ever realise in practice [165f]; the bypassing of contemporary problems of disempowerment $[11,156]$ and timeless predicaments of action in concert).

At the heart of Buckler's enquiry is Arendt's method. Beyond its critique of political philosophy, how does her thinking engage with politics and action? Does she find a way to offer responsible criticism without arrogating an untenable authority to legislate? 
Certainly, Arendt does not aim for the simple agreement of her readers, neither at compelling proofs nor final results (40ff). She affiliates herself with no party or school of thought, nor has she founded any. Her partisanship, as Buckler nicely puts it, is only to politics itself $(51,99,155)$. At the same time, she examines the limits and dangers of politics. In this way, Arendt keeps a reflective distance from politics while ensuring the relevance of her thinking - to actors who are willing to ask what they are doing, to spectators who seek to understand what is at stake, to anyone who wants to come to terms with "what it is all about" (as Arendt liked to put it). In this short appreciation of Buckler's book, I want to highlight the two guiding features of Arendt's method that he brings to the fore: its concern with timeliness and its epistemic relevance to political questions. I conclude with a brief note on Arendt's relation to other ways of approaching political philosophy, as raised by Buckler's book and my own remarks.

\section{Timeliness}

Just as politics always involves acting in an already given situation, thinking about politics requires us to ask what politics means in the circumstances that we now face. Those circumstances can be described at different levels of generality. Each political actor, as a person with a particular identity and social location, faces a slightly different situation. Each polity must confront different and sometimes quite novel issues. Arendt steps back from many of those particularities, but insists that two facts are central to any meaningful engagement with contemporary politics. First, the fact of totalitarianism: given a politically organised and interrelated globe, 'humanity,' as the totality of all living human beings, is no longer a mere abstraction. The quest for total domination not only became thinkable, but was adopted as the political programme of two great powers. This project spelt doom to politics, insofar as we understand that term as reflecting its etymological and experiential root in the Greek polis - as a sphere of civic participation and shared decision-making.

A second fact: in modern liberal democracies, politics has been subordinated to economic and social interests (95f, 146f). Most citizens exercise their right to freedom from politics (149) and expect elected representatives to deliver prosperity and security. Our lives are structured through and through by organisations, in ways that give little scope for collective debate and decision. Both commercial forces and state apparatuses of 'security' have become ever more autonomous: their dynamics evade political accountability and distort the political process. The prosperity and safety they promised look ever more partial and parlous. So too do the spaces for any politics that might challenge them.

In Arendt's view, then, it matters more than ever that we understand the nature, possibilities and limits of politics. Timely reflection recognises that the past cannot guide us through this changed landscape. Never before have we been confronted with such a radical liquidation of human freedom as under totalitarianism; despite their technological and economic powers (22), political disempowerment is a striking feature of our societies. For these and other reasons, there can be no question of reviving past glories. As the example of the Greek polis suggests, these were hardly unambiguous 
achievements; in any event, attempts at restoration founder on the novelty and distinctness of any actual starting point for action (106). Yet the past can still provide illumination. With deliberate violence, Arendt wrests fragments from a sunken and ambivalent inheritance - not least, a gleaming and partial portrait of the polis that its participants would barely recognise (46f, 100). She does so in order to inspire a sense of political possibilities. Contemporary institutions and our "beaten paths of ideologies" (quoted 162f) may seem to foreclose such possibilities. Arendt argues that unexpected openings and new beginnings are intrinsic to politics and its dynamics of action and power.

\section{Relevance}

The search for universal political truths remains alive, if not altogether well, in contemporary political philosophy. Sometimes it is set aside in favour of articulating supposedly shared intuitions or convictions. But does either quest answer to the responsibilities and powers of philosophers? Politics is a realm where differences of opinion are not just foreseeable and not only legitimate. Much more than this: such differences are a cardinal manifestation of human freedom. (I will return to this.) In this light, what contribution can philosophers make and what sort of authority should they assume? Insofar as the philosopher is not a political actor, presumably it makes little sense to lay down a political programme or end-point. Even if others take it as authoritative, even if they gain power, they must respond to particular circumstances and make their own judgments. Whether the inspiration be Marx or Hayek, ideas transmogrify into one ideology among others; achievements bear only flickering and shadowy resemblance to the theorist's answers. Theoretical pronouncements as to what 'we' should do or achieve are defeated by the sphere of action and opinion that the philosopher has (perhaps unwittingly, in any case unrealistically) assumed might operate as a means to realise his or her proposed ends (18).

Arendt defends the integrity and 'potency' $(38,43)$ of politics against such instrumental assumptions. Theorists with legislative ambitions denigrate the freedom of those who act and neglect the power that can only arise through concerted action by people whose opinions never exactly coincide (with the theorist's, with one another's). At first glance, it might seem that the only philosophical response is to throw up one's hands and leave the actors to it - to wash one's hands of politics altogether. Arendt offers an alternative. ${ }^{1}$ Philosophers may ask, just as well as participants in their more reflective moments, what is at stake in politics, what its possibilities and limits are, how it can be sustained or undermined, what its meaning is. These questions are like questions about what 'we' should do or 'achieve' in that they permit no final answer. They are unlike in two respects. They answer to responsibilities that are equally shared by thinkers and actors

In Kantian terms, her position is transcendental. Instrumental or legislative approaches to political theory must look for a transcendent position outside of politics in order to authorise their ambitions. Engagé theorising, that is, theorising that sees itself as a form of action, aspires to an immanent position - but without undertaking the responsibilities, or engaging the resources, of action in concert (166-169). 
(158ff). And they respect the initiative, judgment and courage (136ff) that political actors must exercise if they are to act freely and responsibly.

How we frame and answer these questions depends on many factors: the weight we attach to different values, our interpretation and appreciation of vastly diverse experiences, the balance we strike between immediate possibilities and indefinite aspirations. This lack of closure characterises a realm of freedom and responsibility (26), so that political philosophy stands on an equal footing with political action. As long as they respect this, the philosopher's answers can remain relevant to the actor. However opinionated they may be, they cannot serve as blueprints to achieve or principles that demand "compliance." But philosophers can offer thoughtful explorations of the possibilities, limitations and significance of what political actors are doing or yet to do. After all, it is easier to raise questions about meaning and limits (8), in both their timeless and their timely aspects, from the theoretical sidelines, where the urgency of immediate goals and events recedes.

This said, Arendt is cautious of the outsider's perspective (51) - so ready to abstract in the pursuit of generality or even eternality (169), prone to ignore the predicaments of political action, ill-disposed to the "shock of experience" (quoted 12, 98) and, not least, subject to attempted monopoly by a philosophical few (24). Hence she insists on the thought-provoking and anchoring role of actual events, as shared points of reference that bind actors and thinkers (cf 48, 141). Thought must remain "bound to incident as the circle remains bound to its focus, [otherwise it] is liable to become altogether meaningless or to rehash old verities which have lost all concrete relevance" (quoted 26). As we have already discussed, Arendt sees political reflection as bound to its time. Its relevance is based, in addition, on the acknowledgement of shared experiences, shared responsibilities, and free opinion as the lifeblood of politics - and of thinking.

\section{Freedom in political philosophy}

My summary formulations may lead readers to fear a certain imperiousness in Arendt's warnings against traditional approaches to political philosophy. I think that Arendt avoids this danger, as does Buckler when he insightfully extrapolates her cautions to contemporary political theory (165ff). Indeed, self-consistency demands this of them.

Despite Arendt's mistrust of the philosophical tradition, one of her achievements is to open up another way of thinking about political philosophy, and hence of reading past, present and future contributions. She may interpret Plato as the arch philosophical legislator. But this is just one possible reading, and not necessarily the most persuasive or insightful one. ${ }^{2}$ Nor is it quite typical of the creative appropriations that Arendt elsewhere makes of philosophers' ideas. In any event, when we consider the rich history

Perhaps I should add that it is, nonetheless, a timely reading. That Marx's ideas were realised (and of course perverted) as a totalitarian form of government was a key spur to Arendt's own political philosophy. If one joins Arendt in seeing Marx's thought as born of our whole tradition of political philosophy, then one must also ask whether the seeds of such danger were there at the beginning of this tradition. 
of political philosophy and its best contemporary representatives, it would be unfair and inept to discern only a series of attempts to legislate to political actors (dangerous and distorted when taken up, irrelevant if not). When Mill defends freedom of speech, for example, or Kant argues that the republican state is the only condition that frees us from domination or, indeed, when Rawls asks how justice can be reconciled with disparities in wealth and power, we may read these as enquiries into what is at stake in modern politics, as thoughtful contributions that learn from previous political achievements and articulate timely political hopes.

I have already noted a point well emphasised by Buckler: Arendt sees the space of political thought as having, in its freedom, important parallels with the domain of political action and opinion (26). This is not to say that thought or action are opposed to truth: both depend on the truthful recognition of factual ground and cogency in reasoning. Unlike the traditional search for absolute truth or timeless principles, however, they do not aim at final answers. This is because there is no single or unitary criterion (be it truth or, perhaps, success in solving a supposedly immutable problem) for political judgment, political philosophy, or indeed thought in general. Our criteria must be plural, complex and open-ended. Not the least of these are timeliness and relevance.

Perhaps this permits us to draw a line between genuine contributions to political philosophy, be they more or less 'ideal' or programmatic, and the shallower sorts of theoretical legislation (not to mention deadening technicality) that are so common in academic publishing. The distinction, I suspect, consists in an appreciation of the political realities that Arendt made her focus: ${ }^{3}$ the plurality underlying any 'we,' the fragility of action in concert, the inevitability of disagreement, the difficulties of sustaining power that is not merely coercive and irresponsible, the fact that every 'achievement' is fated to become just another starting point for the next generation. There is no need for each political philosopher to offer sustained reflection on these themes. Decisions as to what is relevant and important permit no final answer; the relevance and timeliness of each contribution depend, in part, on recognition of what has gone before. ${ }^{4}$ Buckler's book shows us a political theorist - indeed philosopher who merits not simple agreement or mere imitation (4f, 169f), but precisely this sort of recognition. ${ }^{5}$

3 Perhaps it goes without saying that there is a special danger of losing this awareness when a philosopher's work becomes entrenched as a school of thought. Disciples can then go at it hammer and tongs over the correct account of a principle, -ism or programme (162f). Terms of debate become fixed as the broader terrain of the original ideas recedes from sight.

4 Not to mention recognition of how other philosophers' ideas have fared in the political realm, be it as ideologies or inspirations - see footnote 2 .

5 I am grateful to Morris Kaplan for helpful comments and discussion. 